\title{
Serum amyloid protein levels in South American children with rheumatoid arthritis: a co-operative study
}

\author{
MORTON A. SCHEINBERG, OSVALDO HUBSCHER, OSVALDO GARCIA \\ MORTEO, AND MERRYL D. BENSON
}

From the Division of Microbiology-Immunology, Pathology Department, Faculdade de Ciências Médicas da Santa Casa de São Paulo; the Bone and Joint Research Unit, Pavilhão Fernandinho Simonsen, Department of Orthopedics; Centro de Educacion Medica e Investigaciones Clinicas CEMIC, Buenos Aires, Argentina, and the Division of Rheumatology, University of Indiana, Indianopolis, USA

SUMMARY Serum amyloid protein (SAA) levels were determined by radioimmunoassay in 90 children with juvenile rheumatoid arthritis (JRA). Significantly higher levels of SAA were present in children with the polyarticular and systemic forms of the disease. SAA levels correlate with disease activity, increasing during acute exacerbations, decreasing during remission and in patients having prednisone therapy. High serum SAA concentrations in children with JRA did not correlate with the presence of secondary amyloidosis and may be useful as a disease monitor.

There is a difference in the frequency of secondary amyloidosis in juvenile rheumatoid arthritis (JRA) in European countries when compared to the frequency reported in North and South America. ${ }^{1-5}$ A number of factors have been suggested as playing a role in the pathogenesis of secondary amyloidosis. However, none of these factors can by itself acount for the difference in the incidence of amyloidosisassociated JRA throughout the world.

During the past 10 years progress has been made in the analysis of the structure and chemical composition of amyloid. Fragments of immunoglobulin have been found to be the major fibril protein in the primary form of amyloid disease. The second type of amyloid protein is a serum protein, SAA, which has the properties of an acute phase reactant.

The SAA protein appears to be the precursor of amyloid AA, which is the amyloid protein associated with secondary amyloidosis encountered in patients with chronic inflammatory conditions such as juvenile theumatoid arthritis. In the present study we have measured the level of serum SAA in South American JRA children with and without

Accepted for publication 1 June 1979

Correspondence to Morton A. Scheinberg, MD, Division of Microbiology-Immunology, Faculdade de Ciências Médicas de Santa Casa de São Paulo, Rua Cesario Motta Jr. 112 CEP-01221, São Paulo, Brazil. amyloidosis and compared it to the levels in patients with JRA from other parts of the world. We have also determined the correlations between SAA levels and the various clinical forms of JRA, disease activity, and the effect of therapy.

\section{Material and methods}

The determinations of SAA levels were performed on a group of 90 children who were seen regularly in the arthritis clinics in 2 different countries, namely, Argentina and Brazil. The Argentinian group consisted of 60 children ( 40 females, and 20 males) with JRA, 4 of them known to have biopsyproved amyloidosis. The Brazilian group consisted of 30 children ( 18 females, and 12 males) with JRA who fulfilled previously established diagnostic criteria. $^{6}$

Serum SAA concentrations were determined by radioimmunoassay. Briefly, SAA antisera was raised in rabbits by the injection of isolated protein $\mathbf{A A}$ in New Zealand white rabbits by serial injections of AA in complete Freund's adjuvant. Radiolabelling of human amyloid protein AA was performed by iodination utilising Hunter's method. ${ }^{7}$

The radiolabelled $\mathrm{AA}$ was stored at $-20^{\circ} \mathrm{C}$ until used. The assay itself was performed by competitive binding as described by Yalow and Berson with small modifications. ${ }^{8}$ The method measures the 
concentration of serum as $\mathrm{AA}$ equivalence in international units $/ \mathrm{ml}$.

\section{Results}

In children with JRA the higher levels of SAA were found in patients with the systemic form of the disease, with a mean value of $3240 \pm 628 \mathrm{U} / \mathrm{ml}$, followed by the polyarticular group with a mean value of $2035 \pm 321$. The oligoarticular group had a mean SAA level of $411 \pm 118$, which differed significantly from the 2 other forms of the disease (Table 1). Children with JRA and amyloidosis had values that were comparable to those observed among the JRA children without amyloidosis.

When JRA patients were grouped according to the activity of the disease, SAA levels were significantly higher in the active group, suggesting that SAA levels may be a good indicator of disease activity (Table 2).

To assess the effect of therapy on SAA levels JRA patients on steroid therapy were compared to those not receiving the medication. The steroid treated group had mean SAA levels $1434 \pm 275$ $\mathrm{U} / \mathrm{ml}$, significantly lower than the nonsteroid group $(2699 \pm 471)$ (Table 3).

No correlation could be established between the Westergren sedimentation rate and serum SAA levels; there was considerable variation from individual to individual.

Table 1 SAA protein levels in South American JRA children: Course of disease

\begin{tabular}{llll}
\hline & Systemic & Oligoarticular 1 & Polyarticular \\
\hline $\begin{array}{llll}\text { SAA protein } \\
\text { (U/ml) }\end{array}$ & $3240 \pm 628$ & $411 \pm 118$ & $2035 \pm 321$ \\
No. of patients & 9 & 10 & 62 \\
SAA protein, normal values $58 \pm 5$ & & \\
\hline
\end{tabular}

$1 \mathrm{P}<0.01$ when compared to the systemic and polyarticular forms.

Table 2 SAA protein levels and disease activity

\begin{tabular}{lll}
\hline & Active & Inactive \\
\hline No. of patients & 55 & 30 \\
SAA protein $(\mathrm{U} / \mathrm{ml})$ & $2573 \pm 3141$ & $363 \pm 108$ \\
\hline
\end{tabular}

$1 \mathrm{P}<0.011$ when compared to the inactive form.

Table 3 SAA protein levels and prednisone therapy

\begin{tabular}{lll}
\hline & Nonsteroidal therapy & Prednisone \\
\hline No. of patients & 60 & 25 \\
SAA protein $(\mathrm{U} / \mathrm{ml})$ & $2699 \pm 471$ & $1434 \pm 275$ \\
\hline
\end{tabular}

$1 \mathrm{P}<0.01$ when compared to the nonsteroidal group.

\section{Discussion}

The present study attempts to correlate serum SAA levels with the various clinical parameters of JRA. High concentrations of SAA protein in serum were found in children with the systemic and polyarticular forms of the disease, particularly if the condition was active at the time of removal of the blood. The activity of the disease in the present study was estimated on the basis of the elevation of the sedimentation rate, number of active joints, and presence of fever and/or arthritis.

The mean concentration of SAA protein in amyloidotic children did not differ from that in nonamyloidotic children, indicating that SAA values cannot be used to assess or predict the development of amyloidosis. This agrees with previous studies. ${ }^{2,9}$ It should be noted that the low frequency of amyloidosis in this study group may in part reflect the small number of children with systemic disease, in whom amyloidosis appears to be a more prevalent condition. The lower levels of SAA protein in children receiving oral steroids correlates with the well known anti-inflammatory properties of these agents and the acute phase reactant behaviour of SAA protein and the previous reported low SAA levels on JRA patients receiving cytotoxic therapy. ${ }^{9}$

In conclusion, these studies show that serum SAA levels in JRA children are not related to the development of secondary amyloidosis. We reported similar findings in experimental studies on mice, where SAA levels do not correlate with the development of casein induced amyloidosis in susceptible and resistant strains of mice. ${ }^{10-12}$. Higher SAA levels are more a reflection of disease activity and the medication used by the patient. The absence of a good correlation between SAA and sedimentation rate suggests, however, that neither of those 2 parameters should be used alone to detect disease activity. The regional differences in the incidence of amyloidosis in JRA throughout the world appear not to be dependent on SAA protein levels but perhaps on other mechanisms that should receive attention.

Grants for these investigations were provided by the Conselho Nacional de Desenvolvimento Cientifico e Tecnologico (CNPq), the Heisen Fellowship for Leprosy Research and the Wellcome Trust.

\section{References}

1 Baum J, Gutowska G. Death in juvenile rheumatoid arthritis. Arthritis Rheum 1977; 20: 253.

2 Filipowicz-Sosnowska F A M, RoztropowiczDenisiewiczk K, Rosenthal C J, Baum J. The amyloidosis of juvenile rheumatoid arthritis-Comparative studies in Polish and American children. The levels of serum SAA protein. Arthritis Rheum 1978; 2: 699-703.

3 Garcia M O, Hubscher $O$. Amyloidosis in juvenile arthritis. Arthritis Rheum 1978; 21 : 867-868. 
4 Roztropowicz-Denisiewiczk K, Maldyk E, Wagner T. Amyloidosis in juvenile rheumatoid arthritis. Ped Pol 1968; 43: 311 .

5 Smith M E, Ansell B M, Bywaters E G. Mortality related to the amyloidosis of Still's disease. Ann Rheum Dis 1968; 27: 137-145.

6 Ansell B, Bywaters E G L, Prognosis in Still's disease. Bull Rheum Dis 1959; 9: 189-192.

7 Hunter W M, Preparation and assessment of radioactive tracers. Br Med Bull 1974; 30: 18-23.

8 Yalow R S, Berson S A. Immunoassay of endogenous plasma insulin in man. J Clin Invest 1960; 39: 1157-1175.
9 Benson D, Cohen A S, Howard A, Bywaters G L, Ansell B. Amyloid protein SAA levels in juvenile rheumatoid arthritis. Arthritis Rheum 1976; 19: 789.

10 Benson M D, Scheinberg M A, Shirahama T, Cathcart E S, Skinner M. Kinetics of Serum Amyloid Protein $\mathrm{A}$ in casein induced murine amyloidosis. $J$ Clin Invest 1977; 59: 412-417.

11 Scheinberg M A, Cathcart E S. New concepts in the pathogenesis of primary and secondary amyloid disease. Clin Exp Immunol 1978; 33: 185-190.

12 Scheinberg M A. Immunology of amyloid disease. A review. Semin Arthritis Rheum 1977; 7: 133-140. 